\title{
PENGEMBANGAN DIAGNOSIS TUBERKULOSIS PADA HEWAN KESAYANGAN ANJING MENGGUNAKAN ANTIGEN SPESIFIK Mycobacterium tuberculosis ESAT-6 DAN CFP-10
}

\section{THE DEVELOPMENT OF A DIAGNOSTIC METHOD FOR TUBERCULOSIS IN DOG USING SPESIFIC Mycobacterium tuberculosis ANTIGEN ESAT-6 AND CFP-10}

\author{
Ida Tjahajati*, Widya Asmara**, Hardyanto Soebono*** \\ * Bagian IImu Penyakit Dalam, Rumah Sakit Hewan Prof. Soeparwi,Fakultas Kedokteran Hewan UGM, Yogyakarta, \\ ${ }^{* *}$ Bagian Mikrobiologi, Fakultas Kedokteran Hewan UGM, Yogyakarta, \\ ${ }^{* * *}$ Bagian Kulit dan Kelamin, Fakultas Kedokteran UGM, Yogyakarta
}

\begin{abstract}
Early diagnosis is one of the important methods to control tuberculosis because this disease is zoonotic which easily spread through the air. Early detection of tuberculosis in dog is also very important since dog as pet animal have a potency to transfer the disease to human or other animals. The discovery of two specific M.tuberculosis antigens, ESAT06 and CFP-10, provide the opportunity to develop a specific diagnostic kit for tuberculosis by using ELISA based on the secretion of IFN- $y$. The development of a tuberculosis diagnostic kit based on this molecular biology and immunological method would provide a good alternative method to detect tuberculosis specially, accurately as early as possible. The result of this experiment would provide contribution for the development of health science and technology, especially in the eradication of tuberculosis.
\end{abstract}

Keywords: diagnosis, tuberculosis, ESAT-6, CFP-10, interferon-gamma.

\section{PENDAHULUAN}

Deteksi interferon-gamma (IFN- $\gamma$ ) dengan stimuli antigen spesifik Mycobacterium tuberculosis ESAT-6 dan CFP-10 menjadi sangat penting untuk deteksi tuberkulosis pada hewan kesayangan seperti anjing, mengingat anjing lebih sensitif terhadap infeksi oleh M.tuberculosis yaitu galur yang menyerang pada manusia (1). Berdasar pada pustaka yang menyebutkan bahwa anjing lebih sensitif terhadap infeksi M.tuberculosis dibanding dengan M.bovis, sehingga mempunyai resiko lebih besar sebagai sumber penularan ke manusia yang ada di sekitarnya, maka deteksi tuberkulosis pada hewan kesayangan anjing perlu terus diupayakan (2). Mengingat tuberkulosis merupakan penyakit zoonosis penting yang masih merupakan problem global dunia, maka urgen tersedianya alat diagnosis yang spesifik dalam rangka pengendalian penyakit. Meskipun jumlah penderita tuberkulosis terus meningkat, dan penyakit bersifat zoonotik, perhatian terhadap tuberkulosis pada hewan kesayangan seperti anjing sejauh ini belum mendapatkan perhatian yang serius (3).

Permasalahan diagnosis tuberkulosis sampai sekarang masih merupakan masalah besar baik pada manusia maupun pada hewan kesayangan termasuk anjing. Diagnosis didasarkan pengenalan antigen spesifik oleh sel

Jurnal Kedokteran Brawijaya, Vol. XXIII, No. 2, Agustus 2007 Korespondensi: Ida Tjahajati; Bagian IImu Penyakit Dalam, RS Hewan Prof Soeparwi, FKH UGM Yogyakarta: email: ida_tjahajati@yahoo.com.
$\mathrm{T}$, yang akan direspon dengan produksi sitokin IFN- $y$, yang dapat dideteksi dengan menggunakan sistem ELISA merupakan dasar yang dapat digunakan untuk menciptakan cara diagnosis penyakit tuberkulosis secara in vitro. Banyak upaya penelitian dikembangkan untuk menemukan antigen spesifik yang dapat digunakan sebagai dasar diagnosis tuberkulosis. Ditemukannya antigen spesifik Mycobacterium tuberculosis yaitu ESAT-6 dan CFP-10 yang dikode oleh gene RD-1 dan RD-2 membuka peluang untuk dapat menciptakan metode diagnosis tuberkulosis yang spesifik $(4,5)$. Berdasar pada limfosit T yang spesifik antigen, yang berarti hanya terstimuli oleh antigen yang spesifik yang pernah dikenalinya, maka dapat diciptakan suatu cara diagnosis yang akurat. Tersekresinya IFN- $y$ oleh limfosit $T$ oleh stimuli antigen spesifik secara in vitro, akan memudahkan deteksi secara cepat, mudah, dan akurat, yaitu dengan sistem ELISA.

Interferon-gamma merupakan sitokin yang dihasilkan oleh makrofag pada respon imun bawaan atau non spesifik, dan dihasilkan oleh limfosit $T$ pada respon imun spesifik $(6,7)$. Sitokin ini dihasilkan oleh limfosit T pada respon imun spesifik sebagai respon terhadap adanya rangsangan dari makrofag yang mempresentasikan antigen melalui MHC-II pada infeksi intraseluler seperti M.tuberculosis complex. Respon imun spesifik oleh sel $T$ terhadap pengenalan antigen M.tuberculosis, memungkinkan pengembangan diagnosis secara in vitro berdasarkan inteferon-gamma yang dihasilkan oleh sel T setelah terstimuli dengan antigen 
yang pernah dikenalinya (sel T memori baik CD4+ maupun CD8+) (5).

Masalah diagnosis tuberkulosis pada hewan kesayangan seperti anjing dan kucing masih merupakan masalah besar, karena uji dengan intradermal (tuberculin skin test, TST) tidak memberikan respon yang baik dan tidak konsisten, anjing dan kucing tidak memberikan reaksi yang nyata pada penyuntikan tuberculin secara intradermal, dan hasil uji kurang dapat dipercaya karena sering terjadi reaksi positif dan negatif semu $(8,9,10,11)$.

Alternatif pemecahan dengan diagnosis secara in vitro merupakan alternatif cara diagnosis yang lebih mudah, dan dengan ditemukannya antigen spesifik M.tuberculosis yang dikenali oleh sel $\mathrm{T}$, maka menjanjikan diagnosis dengan hasil yang spesifik dan akurat. Alternatif ini akan dapat memecahkan permasalahan cara diagnosis tuberkulosis pada hewan kesayangan seperti anjing yang selama ini masih merupakan masalah.

Tujuan umum penelitian adalah untuk membuat sistem ELISA untuk diagnosis tuberkulosis pada anjing, melalui deteksi IFN- $\gamma$ yang disekresi limfosit T menggunakan stimuli antigen spesifik M.tuberculosis ESAT-6 dan CFP-10 secara in vitro. Untuk mencapai tujuan tersebut diperlukan beberapa tahap penelitian, yang diawali dengan pembuatan rekombinan IFN- $\gamma$, pembuatan antibodi primer dan sekunder terhadap IFN- $y$, dan dilanjutkan dengan pembuatan sistem ELISA.

Hasil penelitian sangat bermanfaat untuk pemecahan masalah di lapangan, yang didasarkan pada pendekatan biologi molekuler dan imunologi, yang diharapkan mendukung pengembangan IPTEK di bidang kesehatan khususnya dalam pemberantasan penyakit menular tuberkulosis melalui penyediaan perangkat diagnosis dini. Diharapkan hasil dengan terciptanya perangkat diagnosis bermanfaat untuk menunjang pembangunan nasional khususnya dalam pencegahan penyakit menular, untuk terciptanya sumber daya manusia yang sehat, yang bebas dari penyakit tuberkulosis.

\section{METODE}

Untuk mencapai tujuan penelitian yaitu memperoleh rekombinan IFN-y anjing, dalam penelitian ini digunakan rancangan penelitian yang berupa eksperimental murni (true experimental), sedangkan menurut waktunya, rancangan penelitian menggunakan rancangan jangka panjang (longitudinal).

Tujuan umum penelitian adalah untuk membuat SISTEM ELISA untuk diagnosis tuberkulosis pada hewan kesayangan anjing, melalui deteksi IFN- $\gamma$ yang disekresi limfosit $T$ menggunakan stimuli antigen spesifik $M$. tuberculosis ESAT-6 dan CFP-10 secara in vitro. Untuk mencapai tujuan tersebut diperlukan beberapa tahap penelitian, yang diawali dengan pembuatan rekombinan
IFN- $\gamma$, pembuatan antibodi primer dan sekunder terhadap IFN- $\gamma$, dan dilanjutkan dengan pembuatan sistem ELISA (12). Pada penelitian tahap awal ini, penelitian bertujuan untuk melakukan isolasi mRNA limfosit $T$ galur dari limfa anjing.

\section{Hewan Percobaan}

Sepuluh ekor anjing dewasa (1-2 tahun), sehat didasarkan pemeriksaan fisik dan laboratorik, yang meliputi pemeriksaan darah rutin, uji fungsi hati dan fungsi ginjal. Lima ekor anjing diinfeksi dengan M.tuberculosis galur H37Rv dengan dosis $10^{6} \mathrm{cfu}$, dan 5 ekor anjing lainnya sebagai kontrol tidak diinfeksi.

\section{Isolasi PBMC dan stimulasi dengan PPD}

Setelah diinfeksi, 4 minggu kemudian anjing dieuthanasi untuk diambil limfanya. Limpa kemudian dimasukkan dalam cawan petri yang telah berisi médium RPMI. Kemudian potong-potong limpa dengan gunting sehingga ukuran potongan menjadi kecil. Dengan gerakan sedikit melingkar, tekan potongan ke dasar cawan petri menggunakan spuit, dan gumpalan-gumpalan yang tersisa dihancurkan dengan menyedot larutan dan mengeluarkan kembali ke dalam spuit ukuran jarum 19G. Kemudian larutan dimasukkan ke dalam tabung sentrifus dengan melalui 200- $\mu \mathrm{m}$ mesh nylon screen. Kemudian larutan disentrifus selama 10 menit dengan kecepatan 1000 rpm (200 x g) dan supernatan dibuang. Selanjutnya pelet diresuspensi dengan medium komplit dan jumlah sel PBMC dihitung. Selanjutnya sel PBMC yang diperoleh dikultur dengan menggunakan media penumbuh (growth medium) yang mengandung $2 \%$ penicillin-streptomycin dan 10\% FCS (fecal calve serum), dan distimuli dengan purified protein derivate (PPD) dengan konsentrasi final $5 \mathrm{ug} / \mathrm{ml}$. Pada PBMC kontrol hanya diberikan medium penumbuh saja, tanpa distimuli dengan PPD. Selanjutnya plate diinkubasikan pada suhu $37^{\circ} \mathrm{C}$ dengan $5 \%$ CO2 selama 24 jam, untuk kemudian dilakukan isolasi total mRNA sel limfosit T. Prosedur isolasi mRNA dilakukan sesuai dengan petunjuk pabrik (Invitrogen $R$ ).

\section{HASIL PENELITIAN}

Hasil isolasi limfosit $T$ yang diperoleh dari limfa anjing, selanjutnya dikultur dan distimuli dengan PPD untuk kelompok yang diinfeksi dengan M.tuberculosis, dan tidak diberikan stimuli untuk kelompok kontrol. Sel selanjutnya diproses untuk mendapatkan total mRNA, dan selanjutnya total mRNA diukur dengan menggunakan spektrofotometer pada panjang gelombang 260 . Sampel yang diperoleh dari hasil isolasi total mRNA kemudian diambil 5 ul, selanjutnya ditambahkan $\mathrm{H}_{2} \mathrm{O} 95$ ul (pengenceran 20 kali), dan kemudian dibaca OD yang didapatkan dari pengukuran hasil pengenceran tersebut. Hasil pembacaan, setiap 1 OD pada panjang gelombang 260 adalah setara dengan $40 \mu \mathrm{g}$, sehingga jumlah total mRNA sel limfosit $T$ yang didapatkan 
pada penelitian adalah 40 dikalikan OD yang diperoleh pada pengukuran, dan dikalikan dengan pengenceran.

Gambar proses isolasi limfosit T dari lien kelompok anjing yang diinfeksi dan tidak diinfeksi M.tuberculosis dapat dilihat pada Gambar 1.

Hasil pengukuran total mRNA limfosit $T$ dari kelompok anjing yang tidak diinfeksi dengan M.tuberculosis disajikan pada Tabel 1, sedangkan untuk kelompok yang diinfeksi (kelompok kontrol) disajikan pada Tabel 2.

Tabel 1. Total mRNA limfosit $T$ kelompok anjing yang tidak diinfeksi M.tuberculosis

\begin{tabular}{|c|l|c|}
\hline No. & \multicolumn{1}{|c|}{ Hewan percobaan } & Total mRNA \\
\hline 1 & Anjing 1 & $352 \mu \mathrm{g} / \mathrm{ml}$ \\
\hline 2 & Anjing 2 & $184 \mu \mathrm{g} / \mathrm{ml}$ \\
\hline 3 & Anjing 3 & $256 \mu \mathrm{g} / \mathrm{ml}$ \\
\hline 4 & Anjing 4 & $224 \mu \mathrm{g} / \mathrm{ml}$ \\
\hline 5 & Anjing 5 & $312 \mu \mathrm{g} / \mathrm{ml}$ \\
\hline \multicolumn{2}{|c|}{ Total mRNA yang diperoleh } & $1328 \mu \mathrm{g} / \mathrm{ml}$ \\
\hline \multicolumn{2}{|l|}{ Rata-rata } & $260,2 \mu \mathrm{g} / \mathrm{ml}$ \\
\hline
\end{tabular}

Tabel 2. Total mRNA limfosit T kelompok anjing yang diinfeksi M.tuberculosis (kelompok kontrol)

\begin{tabular}{|c|l|c|}
\hline No. & Hewan percobaan & Total mRNA \\
\hline 1 & Anjing 6 & $544 \mu \mathrm{g} / \mathrm{ml}$ \\
\hline 2 & Anjing 7 & $344 \mu \mathrm{gl} l$ \\
\hline 3 & Anjing 8 & $448 \mu \mathrm{gg} / \mathrm{ml}$ \\
\hline 4 & Anjing 9 & $360 \mu \mathrm{ml}$ \\
\hline 5 & Anjing 10 & $408 \mu \mathrm{m} / \mathrm{ml}$ \\
\hline Total mRNA yang diperoleh & $2104 \mu \mathrm{g} / \mathrm{ml}$ \\
\hline Rata-rata & $420,8 \mu \mathrm{g} / \mathrm{ml}$ \\
\hline
\end{tabular}

Hasil total mRNA sel limfosit $T$ limpa anjing yang dinfeksi dan tidak diinfeksi yang diperoleh pada tahap ini selanjutnya dipakai sebagai bahan untuk tahap penelitian berikutnya, yaitu untuk sintesis CDNA dengan RT-PCR dan kloning gene yang menyandi interferon-gamma, yang selanjutnya untuk memproduksi sitokin interferon-gamma.

\section{DISKUSI}

Penelitian ini membutuhkan waktu yang cukup lama, karena untuk melakukan skrining untuk mendapatkan anjing yang sehat, harus memenuhi kriteria sehat yang didasarkan pada hasil pemeriksaan klinis dan laboratoris, yang meliputi pemeriksaan fisik, pemeriksaan darah, uji fungsi hati dan ginjal. Anjing yang memenuhi syarat kriteria sehat diikutkan dalam penelitian, sedangkan yang tidak memenuhi kriteria sehat tidak dipakai dalam penelitian. Anjing yang telah memenuhi syarat kemudian diadaptasikan dalam kandang penelitian selama satu minggu, dan selanjutnya diberikan perlakuan dengan infeksi kuman M.tuberculosis pada kelompok perlakuan, dan tidak dilakukan infeksi pada kelompok kontrol.

Seperti diketahui bahwa diagnosis tuberkulosis baik pada manusia dan hewan sampai saat ini masih merupakan masalah besar, karena metode diagnosis yang ada mempunyai banyak kelemahan. Dengan ditemukannya antigen spesifik M.tuberculosis ESAT-6 dan CFP-10 yang dikode oleh gene RD1 dan RD2 membuka peluang untuk dapat menciptakan cara diagnosis yang mudah dan spesifik (5).

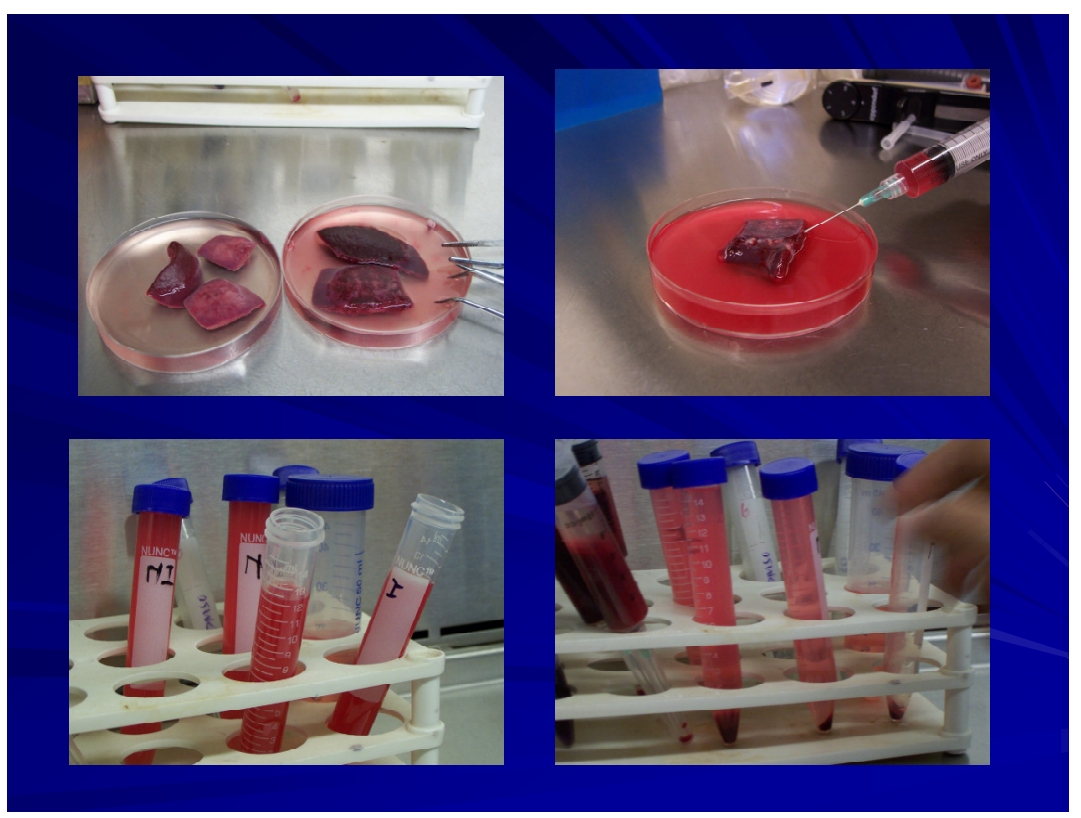

Gambar 1. Isolasi limfosit T dari Lien Anjing yang Diinfeksi dan Tidak Diinfeksi dengan M.tuberculosis 

Gambaran antigen dan gene spesifik yang dimiliki oleh M.tuberculosis dapat dilihat pada Gambar 2 dan Gambar 3. Teknologi diagnosis tuberkulosis yang dilakukan saat ini yaitu menggunakan sistem uji intradermal dengan menggunakan PPD dari biakan kuman M.tuberculosis yang sering dikenal dengan uji tuberkulinasi (Tuberculin Skin Test, TST). Walaupun uji ini merupakan uji yang sampai saat ini diterapkan di lapangan, namun uji ini memiliki banyak kelemahan.

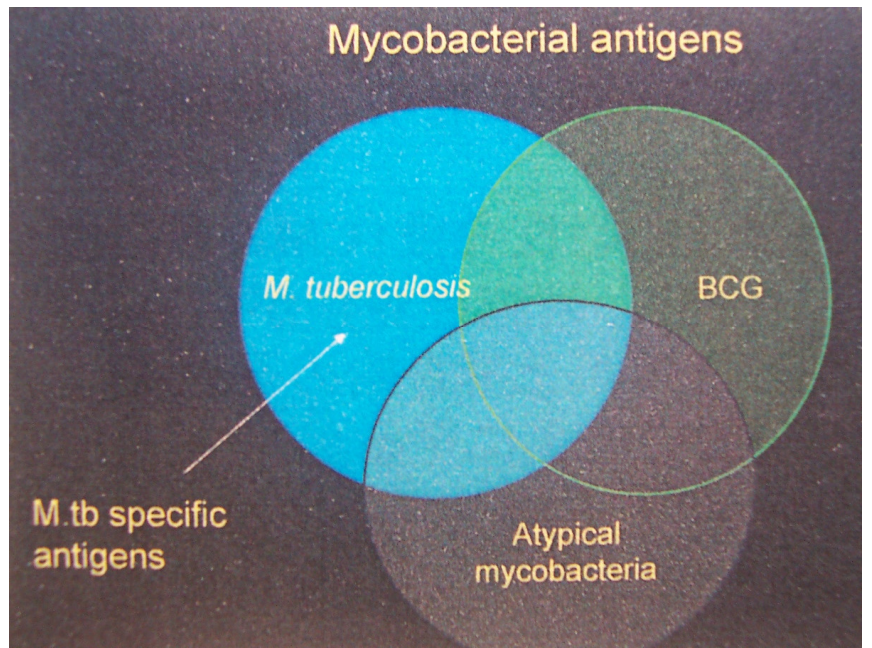

Gambar 2. Gambaran antigen yang dimiliki oleh Mycobacterium (Andersen, 2004) (5).

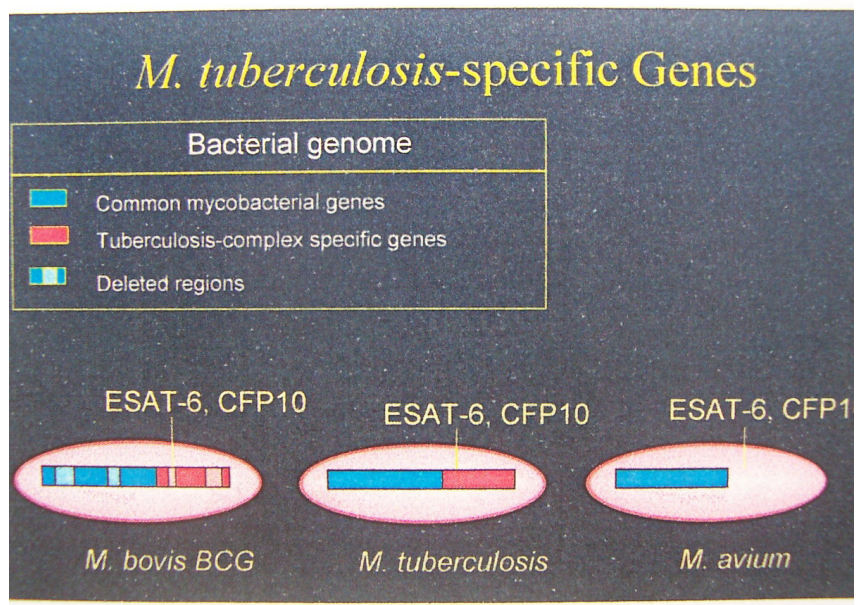

Gambar 3.Gambaran gene spesifik M.tuberculosis (Andersen, 2000) (5)

Kelemahan uji TST antara lain adalah uji dilakukan secara in vitro, sehingga dalam pelaksanaanya membutuhkan waktu yang lama dan kadang respon sangat bervariasi antar individu dan sering juga menimbulkan masalah dalam interpretasi hasil. Stimuli antigen menggunakan PPD yang merupakan crude antigen, jadi bukan merupakan antigen spesifik M.tuberculosis sehingga menyebabkan adanya kemungkinan terjadinya reaksi silang dengan infeksi mikobakterium lainnya. Yang lebih tidak menguntungkan karena uji tidak dapat membedakan apakah hasil uji positif karena infeksi M.tuberculosis atau positif karena pengaruh vaksinasi BCG yang pernah diberikan, sehingga hasil kurang spesifik. Interpretasi hasil uji didasarkan pada perubahan klinis yang berupa penebalan kulit atau indurasi pada tempat suntikan, sehingga sering terjadi interpretasi yang sangat bervariasi dan sering terjadi intepretasi negatif atau positif semu.

Dengan ditemukannya antigen spesifik $M$. TubercuIosis ESAT-6 dan CFP-10 dan adanya sifat kespesifikan sel $T$ dalam merespon terhadap antigen yang pernah dikenalinya, maka membuka peluang untuk dapat menciptakan cara diagnosis alternatif yang dapat mengatasi kelemahankelemahan metode lama. Kelemahan uji sebelumnya yang dilakukan secara in vitro dapat diatasi dengan cara in vivo, yaitu menggunakan darah segar (whole blood) yang mengandung berbagai komponen darah yang didalamnya termasuk limfosit $\mathrm{T}$ yang berperanan dalam mekanisme pertahanan dalam infeksi tuberkulosis. Teknologi sebelumnya yang menggunakan crude antigen (PPD) yang kurang spesifik terhadap infeksi M.tuberculosis dapat digantikan dengan antigen spesifik M.tuberculosis ESAT-6 dan CFP-10 sehingga tidak dikelirukan dengan infeksi mikobakterium yang lainnya. Yang lebih menguntungkan, karena antigen ini tidak dimiliki oleh M.bovis yang merupakan galur yang digunakan untuk vaksinasi BCG, sehingga reaksi positif tidak akan dikelirukan dengan pengaruh vaksinasi BCG yang pernah diberikan. Hasil respon tubuh dari reaksi stimuli antigen yang mengaktifkan sel makrofag dan limfosit $T$ yang pada metode sebelumnya dibaca didasarkan pada perubahan klinis, dapat diukur secara kuantitatif yaitu dengan mengukur aktivitas limfosit $T$ dalam sekresi interferon-gammanya dengan metode ELISA. Berdasar pada berbagai alasan tersebut, maka berbagai invensi untuk perbaikan metode diagnosis yang ada dengan cara yang lebih mudah, akurat, dan spesifik dapat dilakukan. Diagnosis dengan metode ELISA dengan menggunakan antigen spesifik M.tuberculosis akan menawarkan berbagai kelebihan, karena bisa dilakukan secara in vitro, dan menjanjikan hasil diagnosis yang dapat dilakukan secara cepat, mudah, dan akurat.

Perbedaan atau perbaikan terhadap sistem uji yang ada menggunakan teknologi lama dan invensi teknologi baru yang ditawarkan, yang akan dikembangkan untuk diagnosis tuberkulosis pada hewan kesayangan anjing pada penelitian yang dilakukan dapat digambarkan seperti terlihat pada Tabel 3. 
Tabel 3. Perbandingan Cara Diagnosis Menggunakan Teknologi Sebelumnya dan Teknologi Invensi yang Akan Dilakukan

Teknologi sebelumnya:

TST (Tuberculin Skin Test), uji dilakukan secara in vivo

1. Stimuli antigen: menggunakan PPD (crude antigen), bukan antigen spesifik M.tuberculosis

E Hasil uji kurang spesifik, dapat dikelirukan dengan pengaruh vaksinasi BCG atau infeksi oleh mikobakterium yang lain

- Reaksi: didasarkan pada perubahan klinis, sehingga sering terjadi variasi interpretasi, dan sering terjadi negatif atau positif semu
Invensi:

Sistem ELISA, uji dilakukan secara in vitro

- Stimuli antigen: menggunakan antigen spesifik M.tuberculosis ESAT-6 dan CFP10 Hasil uji spesifik terhadap adanya infeksi M.tuberculosis

Reaksi: diukur secara kuantitatif (sekresi IFN-y oleh limfosit T), sehingga kecil terjadi intepretasi negatif atau positif semu Kit diagnosis spesifik untuk hewan kesayangan anjing
Dalam Kit diagnosis yang akan dikembangkan, didasarkan pada respon imun seluler yang bersifat spesifik antigen yang dimainkan oleh limfosit T. Dalam hal ini apabila pasien telah pernah terinfeksi oleh M.tuberculosis, berarti limfosit $T$ nya telah mengenali antigen spesifik yang dimiliki M.tuberculosis (ESAT-6 dan CFP-10). Untuk memastikan bahwa IFN- $y$ yang dihasilkan adalah karena stimuli antigen spesifik M.tuberculosis dan bukan karena oleh stimuli antigen yang lain, maka Kit dirancang dengan menstimuli limfosit T secara in vitro (dalam hal ini dengan mengambil darah pasien, whole blood) kemudian distimuli dengan antigen spesifik M.tuberculosis ESAT-6 dan CFP10, sehingga dapat dijamin bahwa IFN-y yang dihasilkan oleh limfosit $T$ pasien, adalah hanya karena oleh stimuli antigen M.tuberculosis saja, dan bukan oleh antigen yang lain. Inteferon-gamma yang dihasilkan dari supernatan limfosit T pasien secara in vitro dengan rangsangan ESAT-6 dan CFP-10, selanjutnya dapat dideteksi dengan sistem ELISA. Kelebihan lain yang dapat diambil dari pengembangan Kit diagnosis ini, juga karena ESAT-6 dan CFP-10 tidak dimiliki oleh M.bovis, sehingga dapat mengeliminasi pasien yang telah mendapatkan vaksinasi BCG (pasien yang mendapatkan vaksinasi BCG tidak akan memberikan respon positif pada hasil uji).

Metode deteksi keberadaan kuman M.tuberculosis merupakan "gold standar" untuk diagnosis tuberkulosis. Metode konvensional dengan isolasi kuman membutuhkan waktu yang lama. Metode mutakhir yang telah dikembangkan dengan mendeteksi materi genomik yang bertujuan untuk mendeteksi keberadaan M.tuberculosis dalam sample, ternyata juga mempunyai beberapa kendala. Yang menjadi masalah adalah tidak adanya jaminan bahwa M.tuberculosis selalu berada dalam sampel yang dikirimkan, walaupun sebenarnya pasien terinfeksi kuman
M.tuberculosis (karena teknik pengambilan sampel di lapangan yang sulit). Dengan mengambil darah pasien, dan kemudian distimuli dengan ESAT-6 dan CFP-10 secara in vitro, dan sekresi IFN-y supernatan diukur dengan sistem ELISA, maka masalah yang ada akan dapat teratasi.

Pada tahap penelitian awal ini (tahun pertama), baru diperoleh hasil sampai pada tahap terisolasinya total mRNA dari limfa anjing. Pada tahap penelitian berikutnya, pada tahun kedua dan ketiga akan dilanjutkan dengan sistesis cDNA, kloning gene IFN- $\gamma$, dan ekspresi atau produksi IFNү. Selanjutnya, akan dibuat antibodi primer dan sekunder terhadap IFN- $y$, dan selanjutnya sampai terbentuk sistem ELISA untuk penerapan diagnosis. Penelitian sebelumnya terhadap hewan kesayangan kucing yang diinfeksi M.tuberculosis menunjukkan respon puncak peningkatan aktivitas makrofag pada minggu kedua, dan respon pola sitokin Th2 yang dominan pada akhir penelitian $(13,-17)$. Hasil penelitian juga didukung dengan gambaran darah dan gambaran histopatologi adanya infeksi kronis pada akhir penelitian, yang menunjukkan adanya kemungkinana peran hewan kesayangan dalam penyebaran penyakit tuberculosis $(18,19)$. Adanya respon aktivitas limfosit $T$ dalam sekresi IFN- $y$ terhadap stimuli PPD secara in vitro membuka peluang untuk dapat membuat perangkat diagnosis yang dilakukan secara in vitro, sehingga metode diagnosis menjadi lebih praktis dan mudah dalam aplikasinya di lapangan $(20,21)$. Diharapkan dengan terwujudnya cara diagnosis tuberkulosis yang cepat, mudah, dan akurat, akan dapat mendukung program pemerintah dalam pemberanasan penyakit menular khususnya dalam penyediaan alat diagnosis tuberkulosis. Diagnosis dini yang dimulai dari lingkungan sekitar yang memungkinkan bertindak sebagai sumber penularan ke manusia, akan sangat bermanfaat untuk program 
pemberantasan ke depan, mengingat jumlah pasien tuberkulosis terus meningkat dari tahun ke tahun (3).

\section{KESIMPULAN}

Kesimpulan sementara yang dapat diperoleh dari hasil penelitian pada tahap ini adalah bahwa telah dapat diperoleh total mRNA sel limfosit $T$ yaitu sebesar 2104 $\mu \mathrm{g} / \mathrm{ml}$ pada kelompok yang diinfeksi, dan $1328 \mu \mathrm{g} / \mathrm{ml}$ pada kelompok kontrol. Hasil penelitian yang diperoleh pada tahap ini, selanjutnya siap untuk dipakai sebagai bahan penelitian pada tahap selanjutnya, untuk dilakukan RT-PCR untuk síntesis cDNA, kloning gene IFN- $\gamma$, dan selanjutnya dipakai sebagai dasar untuk memproduksi sitokin interferongamma. Cara diagnosis yang didasarkan pada respon spesifik sel $\mathrm{T}$ dalam mensekresi IFN- $\mathrm{Y}$ secara in vitro dengan menggunakan stimuli antigen spesifik M.tuberculosis ESAT-6 dan CFP-10 menggunakan sistem
ELISA, menjanjikan suatu metode diagnosis yang cepat, mudah, dan akurat.

\section{UCAPAN TERIMAKASIH}

Terimakasih penulis sampaikan ke DIKTI yang telah membiayai penelitian ini lewat Program Penelitian Hibah Bersaing Tahun 2006 pada Bidang Kesehatan dengan Nomer Kontrak: LPPM-UGM/178/2006. Penulis juga mengucpakan terimakasih kepada Kepala Laboratorium Mikrobiologi, Balai Kesehatan Daerah Istimewa, Daerah Istimewa Yogyakarta, yang telah memberikan bantuan isolat, dan Kepala Laboratorium Pengujian dan Penelitian Terpadu, UGM, yang telah memberikan ijin untuk menggunakan fasilitas alat selama penelitian berlangsung. Penulis juga mengucapkan terimakasih kepada semua pihak yang tidak dapat penulis sebutkan satu persatu, sehingga penelitian dapat berjalan lancar dan selesei tepat waktu sesuai dengan yang direncanakan.

\section{DAFTAR KEPUSTAKAAN}

1. Acha PN dan Szyfres B. Zoonoses and Cummunicable Diseases Common to Man and Animal. USA, Wasington DC: Pan American Health Organization, 1989; 7-19.

2. Thoen CO. Tuberculosis in Wild and Domestic Mammals. In Tuberculosis Pathogenesis and Control. Bloom, B.R. Editor. American Society for Microbiology, Washington, DC. 1994; 157-162.

3. Manaf A. Permasalahan Pemberantasan Tuberkulosisdi Indonesia. Seminar NasionalTuberkulosisdan Lepra.Yogyakarta:Pusat Kedokteran Tropis UGM. 1997.

4. Andersen P, Munk ME, Pollock JM and Doherty TM. Spesific immune-based diagnosis of tuberculosis. The Lancet; 2000; 9235 (356): 1099-1104.

5. Andersen P. Replacing the tuberculin skin test with a TB specific test - a modern attempt to solve an old problem. One day seminar, Japanese Tuberculosis Meeting, 6 Mei 2004, Tokyo, Japan. 2004.

6. Howard AD, and Zwilling BS. Reactivation of tuberculosis is associated with a shift from type 1 to type 2 cytokines. Clin. Exp. Immunol. 1999; 115: 428-434.

7. Baratawidjaja KG. Imunologi Dasar. 6 Ed. Jakarta: Balai Penerbit Fakultas Kedokteran Universitas Indonesia,. 2004.

8. Hawthorne VM and Lauder IM. Am. Rev. Resp. Dis., 1962; 85: 858.

9. Snider WR. Tuberculosis in canine and feline populations: Review of the literature. Am. Rev. Resp. Dis., 1971; 104:.877-887.

10. Greene CE. Mycobacterial infections. Dalam: Infectious diseases of the dog and cat. Greene CE, Ed. Philadelphia: WB Saunders Co. 1990; 558-572.

11. Gunn-Moore DA, Jenkins PA dan Lucke. Feline tuberculosis: a literature review and discussion of 18 cases caused an unusual mycobacterial variant. Vet. Rec. 1996; 138, 53-58.

12. Coligan JE, Kruisbeek AM, Margulies DH, Shevach EM, and Strober W. Current Protocols in Immunology, Volume III, John Wiley and Sons, Inc, United Stated of America. 1997.

13. Tjahajati I, Projoharjono S, Soebono H, Asmara W, dan Harada N. Aktivitas sekresi reactive oxygen intermediate (ROI) pada makrofag peritoneum kucing yang diinfeksi dengan Mycobacterium tuberculosis. JSV, 2004; XXII (1):46-53.

14. Tjahajati I, Projoharjono S, Soebono H, Asmara W, dan Harada N. Peningkatan aktivitas fagositosis pada makrofag peritoneum kucing yang diinfeksi dengan M.tuberculosis. JSV, 2004; XXII (2):61-65.

15. Tjahajati I, Prodjoharjono S, Soebono H, Asmara W, dan Harada N. The profil of IFN- $\gamma$ and IL-4 production by peripheral blood mononuclear cell from cats infected with M. tuberculosis. I.J. Biotech. 2003; 31-38.

16. Tjahajati I, Projoharjono S, Soebono H, Asmara W, Subronto YW, dan Harada N. Profil sitokin Th1-Th2 terhadap infeksi M.tuberculosis pada kucing. Media Medika Indonesiana. 2004; 39(3):137-145. 
17. Tjahajati I, Prodjoharjono S, Soebono H, Asmara W, Subronto YW, dan Harada N. The profile of IFN-gamma and IL-4 cytokine in cat infected with Mycobacterium tuberculosis. Presentation in "Seminar of Japanese Society Veterinary Science", Japan: Nippon University. April 4, 2004.

18. Tjahajati I, dan Hariono B. Gambaran Darah Kucing yang Terinfeksi dengan M. tuberculosis. Jurnal SainVeteriner, 2005; 23(1): 23-24.

19. Tjahajati I, Projoharjono S, Soebono H, Asmara W, Subronto YW dan Harada N. Gambaran klinis dan histopatologis kucing yang terinfeksi M.tuberculosis. Jurnal Kedokteran Brawijaya, 2004; XX (2) : 82-91.

20. Tjahajati I. Tuberculosis pada kucing: Potensi pengembangan diagnosis tuberkulosis secara in vitro. Seminar Nasional Veteriner dalam rangka Lustrum Fakultas Kedokteran Hewan Universitas Gadjah Maga, 19 September 2006, di Yogyakarta. 2006.

21. Tjahajati I, Asmara W, dan Soebono H. Pengembangan diagnosis tuberkulosis pada hewan kesayangan anjing menggunakan antigen spesifik M.tuberculosis ESAT-6 DAN CFP-10. Seminar Klaster Kesehatan dalam rangka Dies Natalis Universitas Gadjah Mada, Desember 2006, di Yogyakarta. 2006. 
